\title{
Free-LIVING AMOebae (FLA): MORPHOLOGICAL AND MOLECULAR IDENTIFICATION OF ACANTHAMOEBA IN DENTAL UNIT WATER
}

\author{
TRABELSI H.*, SELLAMI A.*, DENDENA F.*, SELLAMI H.*, CHEIKH-ROUHOU F.*, MAKNI F.*, \\ BEN DHIAA S.** \& AYADI A.*
}

\section{Summary:}

The aim of our study was to detect free-living Amoebae (FLA) by morphological methods and to identify Acanthamoeba spp. by PCR in the dental unit water lines (DUWL). Materials and methods: it was a prospective study dealing with 196 water samples collected from DUWL 194 samples taken in the early morning before materials flush and patient consultations and 102 samples taken after consultations). At the same time, 39 samples from tap water were realized. Results: 135 (69\%) samples were positives by the morphological study with morphotypical diversity. The predominant morphotype was the monopodial (39.2\%).

18 strains of Acanthamoeba spp. were detected in DUW $(13.3 \%)$ and three strains in tap water (10\%). The amplification of $18 \mathrm{~S}$ rDNA gene of these strains of Acanthamoeba spp. was positive for all samples. Conclusion: the FLA and Acanthamoeba were isolated both in tap water and in dental unit. The amoeba pathogenicity has not been demonstrated after oral or dental contamination; but the presence of intracellular and pathogenic bacteria in the amoeba could be a source of microbiological risks for patients in case of deep dental care or immunodepression. The improvement of this dental unit was necessary by putting a filter of 0.2 microns porosity before the arrival of the water in hand-pieces allowing the limitation of FLA passage.

KEY WORDS : Acanthamoeba spp., amibe libre, unite dentaire, identification morphologique, PCR, Tunisie.
Résumé : AMIBES LIBRES : IDENTIFICATION MORPHOLOGIQUE ET MOLÉCULAIRE D'ACANTHAMOEBA DANS L'EAU DES UNITÉS DENTAIRES L'objectif de notre étude a été de détecter les amibes libres par des méthodes morphologiques et d'identifier Acanthamoeba spp. par PCR dans l'eau des unités dentaires. Matériel et méthodes : il s'agit d'une étude prospective portant sur 196 prélèvements d'eau à partir des circuits dentaires 194 échantillons réalisés avant purge et consultation des malades et 102 échantillons après consultation des malades) et 39 échantillons d'eau de robinet. Résultats: l'étude morphologique a permis de détecter les amibes libres dans $69 \%$ des échantillons. Le morphotype prédominant était le monopodial $(39,2 \%) .18$ souches d'Acanthamoeba ont été détectées dans l'eau du circuit dentaire (13,3\%) et trois souches dans l'eau de robinet (10\%). L'amplification du gène $18 \mathrm{~S}$ de I'ADN ribosomal de ces souches d'Acanthamoeba spp. a été positive dans $100 \%$ des cas. Conclusion: les amibes libres, dont Acanthamoeba, ont été isolées aussi bien dans l'eau de robinet que dans les unités dentaires. Des cas d'infections amibiennes directement attribuables aux soins dentaires n'ont pas été démontrés, cependant, la présence de bactéries intracellulaires au sein des amibes libres doit être considérée comme un risque potentiel surtout chez les patients immunodéprimés.

L'assainissement de ces unités s'impose au moins par la mise en place d'un filtre de porosité 0,2 microns avant l'étape d'entrée de l'eau dans les circuits dentaires afin de limiter l'éventuel passage des amibes libres.

MOTS CLÉS : Acanthamoeba spp., amibe libre, unite dentaire, identification morphologique, PCR, Tunisie.

unit, the quality of water is of considerable importance since patients and dental staffs are regularly exposed to water and aerosols generated from the unit. However, dental water may become heavily contaminated with FLA, bacteria and fungi. Indeed, dental hand pieces were connected to dental unit by a network of small-bore plastic tubing through which water and air were propelled to activate or cool down the instruments. Hydrodynamics shows that the water column inside the small lumen moves in the center of the tubing leaving a thin layer of liquid virtually undisturbed against the walls. Water stagnation associated with this physical state creates biofilms. This phenomenon increases the concentration and favours the proliferation of FLA, which are considered important hosts for Legionella pneumophila, Pseudomonas aeruginosa and other pathogenic bacteria (Rodrigues et al., 2005). The amoeba pathogenicity has not been demon-

\footnotetext{
* Fungal and parasitic molecular biology laboratory, Sfax School of Medecine, Magida Boulila Street, 3029 Sfax, Tunisia.

** Regional unit of medical school and university, Sfax, Tunisia. Correspondence: Pr Ali Ayadi.

Tel./Fax: 0021674247130 - E-mail: ali.ayadi@rns.tn
} 
strated after oral or dental contamination; but the presence of intracellular and pathogenic bacteria in the amoeba such as Legionella pneumophila, Pseudomonas aeruginosa and non tuberculous mycobacteria is particularly dangerous for patients with decreased immunity (Szymanska, 2004).

The aim of our study was to detect FLA by morphological methods and to identify Acanthamoeba spp. by PCR in the dental unit water.

\section{MATERIALS AND METHODS}

\section{SAMPLE COLLECT AND CULTURE OF AMOEBIC ISOLATES}

I $\mathrm{t}$ was a prospective study, during six months (April 2007-September 2007), dealing with 196 water samples collected from dental unit water (DUW) of the regional unit of medical school and university of Sfax (south of Tunisia). Dental unit canalizations were connected directly to municipal distribution systems for potable water and there is two filters $20 \mu \mathrm{m}$ porosity placed before the arrival of the water in dental hand-pieces. Two different collects were realized one day during the week from tumblers, spittoons and dental instruments (air-water syringes, turbines and porphy-angles). The first collect (94 samples) was taken in the early morning before materials flush and patient consultations. The second collect (102 samples) was taken after consultations. At the same time, 39 samples from tap water were realized.

$500 \mathrm{ml}$ of each water sample was filtered through cellulose acetate filter $0.45 \mu \mathrm{m}$ porosity under a weak vacuum. The filters were suspended in $8 \mathrm{ml}$ of PAS solution $1 \times .1 \mathrm{ml}$ of various amoebae suspensions obtained from each filter solution was inoculated on $1.5 \%$ non nutrient agar plates seeded with $E$. coli suspension. The samples were incubated at $25^{\circ} \mathrm{C}$ and examined after 3-5 days under a light microscope. A piece of agar plates covered with Acanthamoeba was placed in axenic liquid culture medium PYG slightly modified and incubated at $25^{\circ} \mathrm{C}$ (Shuster, 2002).

The strain (Linc-AP1) of Acanthamoeba polyphaga used was isolated by T.J. Rowbotham, Public Health Laboratory, Leeds, United Kingdom.

\section{MiCROSCOPIC EXAMINATION}

Amoebae in cultures were observed directly and after stains (Giemsa, trichrome, nuclear read and ethylene bleu) by using a light microscope at $100 \times, 400 \times$ and $1000 \times$ magnification. The genus Acanthamoeba was identified from the FLA based on its distinctive feature of trophozoites and cysts, particularly the doublewalled cyst shape. For the classification, the Pussard \& Pons (1977) and Page (1988) keys were applied.

\section{EXTRACTION OF NUCLEAR DNA}

The cells collected from liquid culture PYG were centrifuged $(1000 \mathrm{~g})$ for $10 \mathrm{~min}$ at $4{ }^{\circ} \mathrm{C}$ and washed for three times with PBS (phosphate-buffered-saline) $\mathrm{pH}$ 7.2. Then, the sediment was resuspended in lysis buffer $(50 \mathrm{mM} \mathrm{NaCl}, 10 \mathrm{mM}$ EDTA, $50 \mathrm{mM}$ Tris- $\mathrm{HCl}$, $\mathrm{pH}=8$ ) and incubated at $56^{\circ} \mathrm{C}$ for one hour in association with $10 \mathrm{mg} / \mathrm{ml}$ proteinase $\mathrm{K}$. The genomic DNA was extracted using phenol-chloroform method. Until used, the DNA was stored at $-20^{\circ} \mathrm{C}$.

\section{PCR OF THE SSU RDNA}

For molecular identification, the primers $\mathrm{P} 3 / \mathrm{P} 4$ were used. P3 (5' CCGAATTCGTCGACAACTGTTGATCCT GCCAGGT 3') and P4 (5' GGATCCAAGCTTGATCCTT CTGCAGGTTCACCTAC 3') (Bhattacharya et al., 1998; Chung et al., 1998). All amplification reactions of PCR were performed in a $50 \mu \mathrm{l}$ mixture containing $50 \mathrm{ng}$ DNA, $0.2 \mathrm{mM}$ each of dATP, dCTP, dGTP, dTTP, $50 \mathrm{mM}$ of $\mathrm{MgCl}_{2}, 2 \mu \mathrm{SAB}$ (serum albumin bovin), $20 \mathrm{pmol}$ of each primer and 2.5 UI of GoTaq DNA polymerase (Promega, Madisson, USA). PCR consisted of $1 \mathrm{~min}$ denaturation at $94^{\circ} \mathrm{C}, 1 \mathrm{~min}$ hybridation at $64^{\circ} \mathrm{C}$ and 2 min elongation at $72^{\circ} \mathrm{C}$. After 30 cycles, $10 \mathrm{~min}$ of extension time at $72^{\circ} \mathrm{C}$ was done. Finally, the PCR products were cheeked by electrophoresis in a $1.5 \%$ agarose gel.

\section{RESULTS}

\section{MORPHOLOGICAL STUDY}

4 LA were detected in 135 sample collect (69\%): 69 positive before flush (51.1\%) and 66 positive after flush and consultations (48.8\%) ( $\mathrm{p}>0.1)$. Six different morphotypes were detected: monopodial (39.2 \%), dactylopodial (31.8\%), fan shaped (29.6 \%), acanthopodial (26.6 \%), eruptive (10.3 \%) and rugosa (8.1\%). The morphotype frequency was variable according to the moment of isolation (Fig. 1). Two or more morphotypes were associated in the same culture in $71 \%$

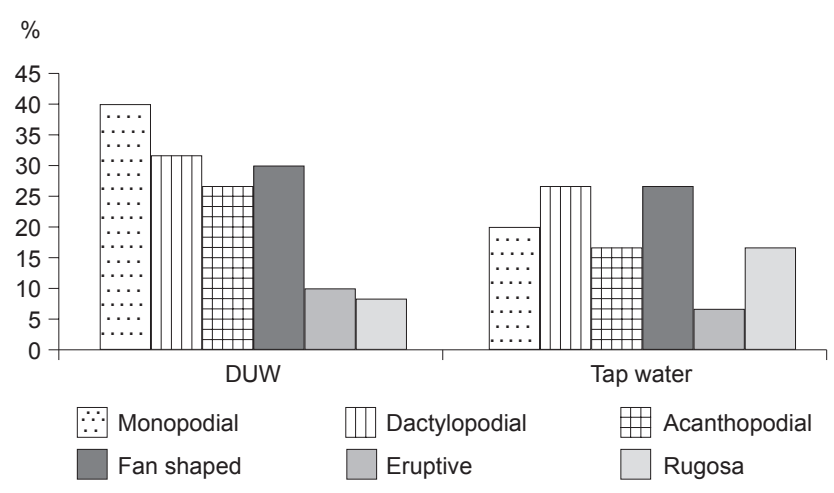

Fig. 1. - Frequency of FLA morphotypes in dental unit and tap water. 


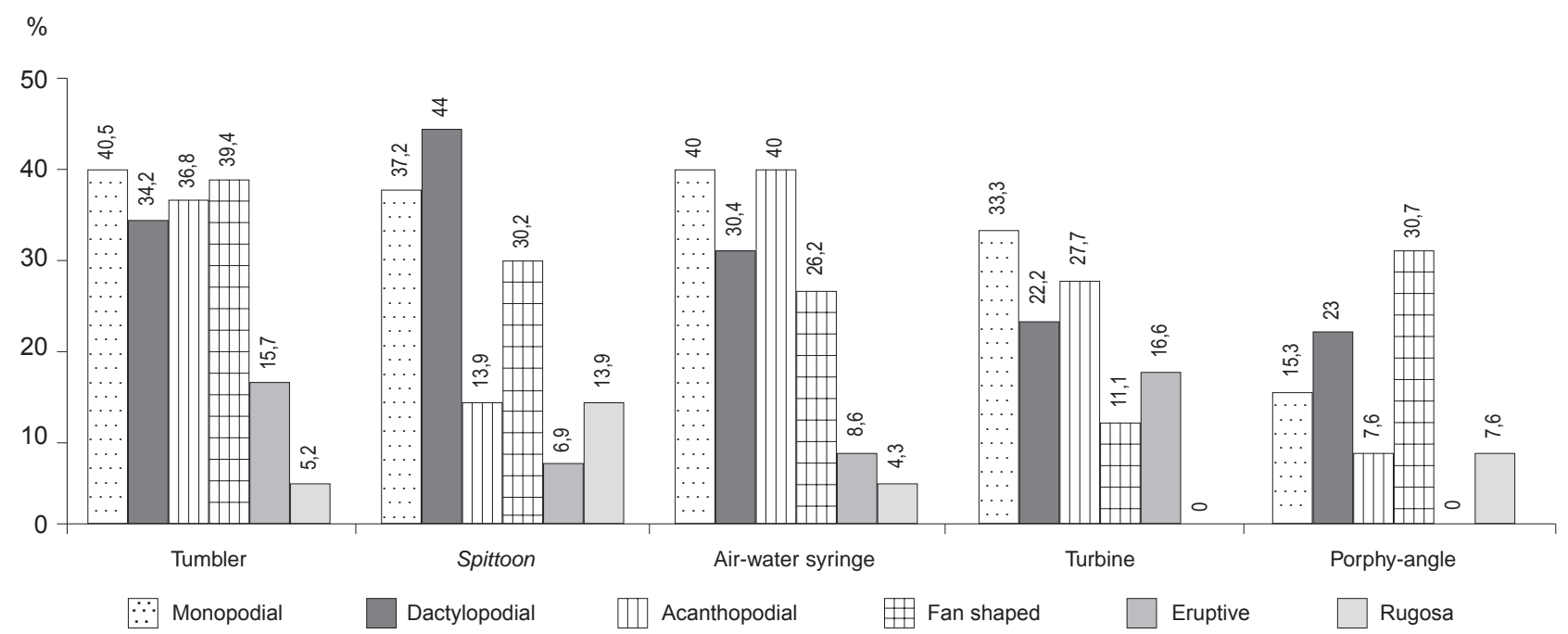

Fig. 2. - Frequency of FLA morphotypes in the different points of collection.

of cases. FLA were detected in spittoon (31.8\%), tumbler (28.1\%), air-water syringe (17\%), turbine (13.3\%) and prophy-angle (9.6\%). In the tap water, 30 samples (77\%) containing different amoebae morphotypes frequency: dactylopodial and fan shaped (26.6 \% each), monopodial (20\%), acanthpodial and rugosa (16.6\% each), eruptive (6.6 \%) (Fig. 2). There was no significant amoebae frequency variation between DUW and tap water ( $\mathrm{p}>0.1$ ).

18 strains of Acanthamoeba spp. (13.3\%) were detected (ten samples in the first collect and eight in the second collect): five in each of spittoons, bottles and syringes, two in the porphy-angles and one in the turbine. In tap water, Acanthamoeba was detected in three samples $(10 \%)$.

The Acanthamoeba cysts detected in our samples belonged to the morphological group II of Pussard \& Pons (1977) and Page (1988).

\section{MOLECULAR STUDY}

PCR amplification, with primers $\mathrm{P} 3 / \mathrm{P} 4$, of the 21 samples identified as Acanthamoeba spp, showed the presence of a band of $2.3 \mathrm{~kb}$ in all cases.

\section{DISCUSSION}

T To the best of our knowledge, this is the first study reporting on the morphological and molecular detection and identification of FLA and Acanthamoeba genus in the dental unit waters of Tunisia. A previous study was performed in a dialysis unit (Dendena et al., 2008).

A wide range of microorganisms has been isolated from DUW, including fungi, FLA, opportunistic and human pathogen bacteria (Parrott et al., 1982; Pankhurst et al.,
2003), but few studies were published about the diseases related to dental water. Only Pseudomonas aeruginosa derived from DUWL has been reported to give rise to infections in two immunocompromised patients (Martin, 1987). Pneumonia, cerebral infections and gastrointestinal disorders caused by waterborne microorganisms, although possible, would be difficult to link to a dental unit (Pankhurst et al., 1998; Barbeau et al., 2000). Eye infection with Acanthamoeba after accidental splatter has been reported, but the proofs were absent (Barbeau et al., 2000). There is no evidence of a widespread public health problem from exposure to DUW. Nevertheless, the goal of infection control is to minimize the risk from exposure to potential pathogens and to create a safe working environment in which to treat patients (Pankhurst \& Johnson, 1998). Free amoebae, and particularly Acanthamoeba spp., were isolated in both DUW and tap water coming from municipal distribution systems for potable water. Even if chlorinated, this water hosts a diverse micro flora of bacteria, yeasts, fungi, viruses, protozoa, unicellular algae and nematodes. In fact, water is considered as potable if it contained less then one fecal coliforms/100 $\mathrm{ml}$ and less then $500 \mathrm{UFC} / \mathrm{ml}$ (CDC, 2003).

In our study, FLA have been isolated from $69 \%$ of DUW samples and Acanthamoeba accounted for $13.3 \%$ which was similar to the study of Michel \& Just, (1984) whose found $12 \%$ of Acanthamoeba in DUW. Barbeau et al. (2001) found that all DUW samples contained amoebae while Acanthamoeba species were detected in $40 \%$ of samples.

Our water samples were collected at different moments but there was no significant amoebae frequency variation between the two collects. This was probably due to an ineffective material flush, water stagnation inside the canalizations and biofilm formation. Therefore, it 
was necessary, every morning, to flush hand-pieces and dental circuits before the first patient, during 5 at $8 \mathrm{~min}$ for reducing at the minimum the microorganism proliferation (Whitehouse et al., 1991; Barbeau et al., 2000). Barbeau et al. (2001) suggested that flushing dental unit water for 2 min was indispensable and can reduce the number of amoebae by $66 \%$. In addition, DUW should be flushed for 30 to 45 seconds between the patients (Barbeau, 2007) for reducing the number of oral microorganisms that may have been retracted into the lines after each patient. In addition, in our dental unit, there was two $20 \mu \mathrm{m}$ porosity filters before the arrival of the water to hand-pieces. So, a pore size of 0.2 microns is recommended for limiting the passage of different FLA (Pankhurst \& Johnson, 1998).

In DUW, all isolates of Acanthamoeba belonged to the morphological group II of Pussard \& Pons (1977). Kong et al. (2002) find the same morphological type in the majority of contact lens storage cases in Korea.

We have completed our investigation by a molecular study of Acanthamoeba spp., which is pathogenic. The band size of A.polyphaga reference strain was $2.3 \mathrm{~kb}$. This same band has been detected in all our samples. It could be also DNA amplification of other pathogenic species ( $A$. castellanii, A. culbertsoni, A. batchetti, A. bealyi, A. lugdunensis, A. triangularis, A. palistinensis or A. rhysodes) (Chung et al., 1998; Liu et al., 2005). So, sequence analysis of $18 \mathrm{~s}$ rDNA is a necessary stage for the identification of different Acanthamoeba species. This first study must be completed by the detection of microorganisms whitch can be carried by FLA.

\section{REFERENCES}

BARBEAU J. Les films biologiques d'origine hydrique et la dentisterie : la nature changeante du contrôle des infections. Journal of the Canadian Dental Association, 2000, 66, 539541.

Barbeau J. \& Buhler T. Biofilms augment the number of freeliving amoebae in dental unit waterlines. Research Microbiology, 2001, 152, 753-760.

Barbeau J. Poursuite judiciaire contre un dentiste concernant une infection oculaire grave possiblement liée à l'eau de la turbine. Journal of the Canadian Dental Association, 2007, 73, 618-622.

Bhattacharya D., Helmchen T. \& Melkonian M. Molecular evolutionary analyses of nuclear-encoded small subunit ribosomal RNA identify and independent rhizopod lineage containing the euglyphina and the chlorarachniophyta. Journal of Eukaryotic Microbiology, 1995, 42, 65-69.

CDC. Guidelines for Infection Control in Dental Health-Care Settings. MMWR, 2003, 52 (RR17), 1-61.

Chung D.I., Yu H.S., Hwang M.Y., Kim T.H., Kim T.O., Yun H.C. \& Kong H.H. Subgenus classification of Acanthamoeba by ribotyping. The Korean Journal of Parasitology, 1998, 36, 69-80.
Dendena F., Sellami H., Jarraya F., Sellami A., Makni F., CheiKhrouhou F., Hachicha J. \& AYADI A. Free-living Amoebae: detection, morphological and molecular identification of Acanthamoeba genus in the hydraulic system of an haemodialysis unit in Tunisia. Parasite, 2008, 15, 137-142.

Kong H.H., Shin J.Y., Yu H.S., Kim J., Hahn T.w., Hahn Y.H. \& Chung D.I. Mitochondrial DNA restriction fragment length polymorphism (RFLP) and small-subunit ribosomal DNA PCR-RFLP analyses of Acanthamoeba isolated from contract lens storage cases of residents of southwestern Korea. Journal of Clinical Microbiology, 2002, 40, 1199-1206.

Liu H., Moon E.K., Yu H.S., Jeong H.J., Hong Y C., Kong H.H. \& CHung D.I. Evaluation of taxonomic validity of four species of Acanthamoeba: A. divionensis, A. paradivionensis, $A$. mauritaniensis and $A$. rhysodes, inferred from molecular analyses. The Korean Journal of Parasitology, 2005, 43, 7-13.

Martin M.V. The significance of the bacterial contamination of dental unit water systems. British Dental Journal, 1987, 163, 152-154.

Martinez A.J. \& Visvesvara G.S. Free-living, amphizoic and opportunistic amoebae. Brain Pathology, 1997, 7, 583-598.

Michel R. \& Just H.M. Acanthamoeba, Naegleria and other free-living amoebae in cooling and rinsing water of dental units. Zentralblatt fur Bakteriologie, Mikrobiologie und Hygiene, 1984, 179, 56-72.

Page F.C. A new key to freshwater and soil Gymnamoebae. Freshwater Biological Association, Ambleside, UK, 1988, 122.

PANKHURST C.L. \& JoHNSON N.W. Microbial contamination of dental unit waterlines: the scientific argument. International Dental Journal, 1998, 48, 359-368.

Pankhurst C.L., Coulter W., Philpott Howard J.J., Harisson T., Warburton F. \& Platt S. Prevalence of legionella waterlines contamination and Legionella pneumophila antibodies in general dental practitioners in London and rural Northern Irland. British Dental Journal, 2003, 195, 591594.

Parrott P.L., Terry P.M., Whitworth E.N., Frawley L.W., Coble R.S., Wachsmuth I.K. \& McGowan J.E. Pseudomonas aeruginosa peritonitis associated with contaminated poloxamer-iodine solution. Lancet, 1982, 2, 683-685.

Pussard M. \& Pons R. Morphologie de la paroi kystique et taxonomie du genre Acanthamoeba (Protozoa: Amoebida). Protistologica, 1977, 13, 557-598.

Rodrigues S., Shenoy V. \& Joseph M. Changing face of infection control: dental unit water lines. The Journal of Indian Prosthodontic Society, 2005, 4, 170-174

SCHUSTER F.L. Cultivation of pathogenic and opportunistic freeliving amoebas. Clinical Microbiology Review, 2002, 15, 342-354.

SZYMANSKA J. Risk of exposure to Legionella in dental practice. Annals of Agricultural and Environmental Medicine, 2004, 11, 9-11.

Whitehouse R.L.S., Peters E., Lizotte J. \& Lilge C. Influence of biofilms on microbial contamination in dental unit water. Journal of Dentistry, 1991, 19, 290-295.

Reçu le 24 avril 2009 Accepté le 12 novembre 2009 